\title{
A Competitividade e o Grau de Concentração das Exportações do Complexo Soja do Brasil, da Argentina e dos Estados Unidos da América No Período 1995/2010
}

\author{
Guilherme da Silva Freitas', Angélica Massuquetti' \\ 'Programa de Pós-Graduação em Economia (PPGE) - Universidade do Vale do Rio dos Sinos (UNISINOS)
}

\begin{abstract}
Resumo
O objetivo deste artigo foi analisar a competitividade das exportações do complexo soja do Brasil, da Argentina e dos EUA e identificar o grau de concentração dos principais mercados de exportação desses países para os anos de 1995 e de 2010. A metodologia empregada foi a CR e o IVCR. Os resultados revelaram que, a partir da mensuração da $\mathrm{CR}_{3}$, a Argentina e o Brasil apresentaram aumento da concentração na soja mesmo triturada e no óleo de soja bruto, enquanto para os EUA, o grau de concentração aumentou na soja mesmo triturada e o óleo de soja mesmo fracionado. Em relação à mensuração do IVCR, observaram-se vantagens comparativas para todos os produtos/países, nos anos de 1995 e 2010. A exceção foi a farinha de soja para o Brasil e a Argentina. Para os EUA, observaram-se índices menores, quando comparados aos demais países, porém permanece sua liderança na exportação de farinha de soja, de óleo fracionado e de soja mesmo triturada.
\end{abstract}

Palavras Chave: Complexo soja; Comércio internacional; Competitividade.

\begin{abstract}
This paper analyzes the export competitiveness of soybean in Brazil, Argentina and the United States and the degree of concentration in the main export markets of these countries in the period 1995/2010, using both the index of Revealed Comparative Advantage (RCA) and Concentration ratio (CR). The results reveal, based on the $\mathrm{CR}_{3}$, that Argentina and Brazil show an increase in the concentration ratio of even crushed soybeans and crude soybean oil, while the US in even crushed soybeans and fractionated soybean oil even. The RCA index shows advantages for all products/countries in both years, except the soy flour to Brazil and Argentina that had values below one. For the US the indexes were lower when compared to the other countries, although it remained as the main exporter of soy flour, fractionated soybean oil even and even crushed soybeans.
\end{abstract}

Keywords: Keywords: Soybean complex; International trade; Competitiveness 


\section{INTRODUÇÃO}

O cultivo da soja tem relevância no agronegócio pela crescente inserção da commodity no mercado mundial, caracterizando-se pelo domínio das exportações de três países: Brasil, Argentina e Estados Unidos da América (EUA). Ressalta-se que a comercialização de grande parte das commodities agrícolas - e mais especificamente da soja - possui uma estrutura complexa. Tal argumento se refere ao fato de que a competitividade entre os países envolve questões políticas e econômicas, como, por exemplo, subsídios à produção agrícola, fornecidos normalmente por nações mais desenvolvidas, barreiras tarifárias e não tarifárias, taxas de importação, quotas, intervenções governamentais, acordos comerciais, entre outras que caracterizam o mercado internacional. Concomitantemente a estas situações, há que se destacar também a importância das condições naturais favoráveis, uma vez que se torna mais vantajoso produzir em algumas regiões e, consequentemente, consumir em outras (CORONEL et al., 2009).

Coronel et al. (2009) lembram que todas as situações citadas anteriormente (políticas, econômicas ou naturais) admitem que pequeno número de países ou até mesmo um único país domine as exportações de determinadas commodities no comércio internacional e, assim, exerça o seu poder de mercado. Neste contexto, a estrutura competitiva do mercado referente à soja e seus derivados tinha os EUA como o principal fornecedor até a metade da década de 1990. A partir de então, a atenção foi desviada para os dois principais países da América do Sul, que juntos vêm aumentando o volume produzido do grão.

A similaridade do complexo soja que existe entre Brasil e Argentina reside, principalmente, na coincidência das etapas de desenvolvimento do setor, uma vez que esta cultura começou de forma inexpressiva na década de 1970 e, a partir dos anos 1990, com ganhos de mercado e consolidação no mercado mundial (BARBOSA; NOGUEIRA Jr, 2007). A entrada do Brasil no mercado internacional da soja deu-se no início da década de 1970, quando a demanda superou a oferta mundial e os EUA, que controlavam 95\% do mercado exportador da soja, declararam embargo no comércio do produto para proteger as necessidades internas (BERTRAND et al., 2012). Já a Argentina expandiu suas atividades apenas na década posterior, contribuindo para a transformação de um mercado quase monopolístico para um nível de maior competição.

Segundo USDA (2013), os EUA são os maiores exportadores de grãos, atingindo, aproximadamente, $44 \%$ do volume total comercializado mundialmente, em 2010/2011. O país é o principal responsável pela formação dos preços da soja no mercado mundial. Já a Argentina possui, para o mesmo período analisado, uma participação significativa nos derivados da oleaginosa: $47 \%$ do mercado de farelo e $48 \%$ do mercado de óleo. Por este motivo, consegue obter maior faturamento quando comparada ao Brasil devido à agregação de valor ao produto em seu próprio território. $\mathrm{O}$ Brasil, por fim, é considerado o segundo maior exportador de grãos, com $32 \%$ do total exportado no mundo e disputa com a Argentina a primeira posição na exportação dos derivados de soja, uma vez que sua contribuição é de $17 \%$ no mercado de óleo e de $24 \%$ no comércio de farelo, na safra 2010/2011.

O aumento da demanda e, por conseguinte, da oferta de soja em todo o mundo deveu-se a diversos fatores. Entre eles está a ampliação do consumo humano e animal; as novas possibilidades nas condições de cultivo - duas safras ao ano; e a elevação da remuneração ao produtor em relação a outras oleaginosas. Desse modo, estes motivos tornam possível a criação de vantagens competitivas nos preços aos consumidores, que, por sua vez, fazem expandir o mercado e a competitividade em nível internacional.

Dada a crescente importância da produção da soja, observa-se no mercado mundial uma busca cada vez mais acirrada pelo market share. Para tanto, a eficiência produtiva em termos qualitativos e quantitativos, com o intuito de atender às necessidades do mercado, provoca transformações tanto na produtividade da cultura como também no aumento da competitividade deste mercado (VALARINI; KUWAHARA, 2007).

Com relação a uma maior produtividade, o melhor instrumento a ser utilizado, segundo Schumpeter (1994), é o incremento da tecnologia. Segundo o autor, a inserção da inovação tecnológica possibilita uma mudança no sistema econômico, melhora as estruturas produtivas e permite criar diferenciações frente à concorrência exacerbada. Já o aumento da competitividade advém de reformas que permitam ao setor desenvolver-se, ou seja, elevar o fluxo comercial entre os países sem que sejam gerados privilégios.

Foi neste sentido que, em 1994, ao fim da Rodada Uruguai, se estabeleceu o Acordo Agrícola. No que se refere à agricultura, foi uma solução diplomática para o impasse que se arrastava e permitiu fechar a Rodada, extinguir o General Agreement on Tariffs and Tade (GATT), criar a Organi- 
zação Mundial de Comércio (OMC) e tratar novos temas emergentes, impedidos até então pelo não término da Rodada anterior (MASSUQUETTI et al., 2012; DEBAR, 2002).

As regras estipuladas pela Rodada Uruguai não convergiram para uma maior liberalização do comércio. Desse modo, a manutenção de práticas intervencionistas tem reduzido a competitividade, uma vez que os países em desenvolvimento são diretamente afetados praticamente em toda cadeia produtiva. Ademais, países em desenvolvimento, como Brasil e Argentina, sofrem restrições ao crescimento da soja devido às deficiências existentes em relação à infraestrutura, à falta de investimentos do Estado, ao custo da terra, à logística para o escoamento da produção, aos preços dos insumos etc. (BARBOSA; NOGUEIRA JR., 2007).

Outra característica do complexo soja é o predomínio de capitais estrangeiros e da centralização desse capital. A apropriação dos benefícios gerados nesse setor por um grupo de empresas multinacionais tem se intensificado no Brasil, na Argentina e nos EUA. Conhecido como o grupo $A B C D$, por conveniência alfabética de suas iniciais, as empresas do setor sojícula, como a Archer Daniels Midland Company (ADM), Bunge, Cargill e Louis Dreyfus, representam entre $75 \%$ e $90 \%$ do comércio mundial (OXFAM, 2011).

Com relação aos capitais estrangeiros, nos anos 1990, Brasil e Argentina foram polos importantes de atração de Investimento Estrangeiro Direto (IED). Segundo UNCTAD (2012), o Brasil passou da $15^{\mathrm{a}}$ posição para a $5^{\mathrm{a}}$, de 2009 para 2010, no ranking dos países que mais receberam investimentos estrangeiros. As estimativas são de que o país recebeu um total de US\$ 48,4 bilhões, valor $86 \%$ superior aos US\$ 25,9 milhões atraídos em 2009. Já a Argentina fica aquém quando comparada com o Brasil, ou seja, mesmo com um incremento de $76 \%$, em 2010 , o volume registrado para o país ainda é pouco expressivo, correspondendo a US\$ 7 bilhões.

O fluxo de IED, no mundo, cresceu $5 \%$, em 2010, subindo para US\$1,244 trilhão na comparação com 2009. Os EUA acompanharam essa tendência e, assim, continuaram a liderar, uma vez que o país recebeu $49,3 \%$ a mais em 2010 , passando de US $\$ 152,8$ bilhões para US $\$ 228,2$ bilhões (UNCTAD, 2012).

A expansão desses investimentos sinaliza a elevação da capacidade produtiva, a geração de inovação e o aumento das exportações. O potencial competitivo dos principais produtores/ exportadores da soja, juntamente com o aumento da demanda fez este setor desenvolver-se, aumen- tando as exportações e mantendo boas perspectivas de crescimento no futuro.

Portanto, considerando a importância da habilidade de um país manter ou aumentar sua participação no mercado de uma determinada indústria de forma sustentável, torna-se relevante investigar, no contexto do complexo soja, a competitividade existente entre Brasil, Argentina e EUA no comércio internacional. Desta forma, o problema de pesquisa que orienta esse artigo é: a partir da importância do complexo soja para as economias brasileira, argentina e estadunidense, qual é a competitividade e o grau de concentração das exportações destes países para os anos de 1995 e de 2010 ? O objetivo geral é analisar a competitividade das exportações da soja mesmo triturada, do farelo de soja, da farinha de soja e do óleo de soja bruto e fracionado do Brasil, da Argentina e dos EUA e identificar o grau de concentração dos principais mercados de exportação desses países para os anos de 1995 e de 2010. Com relação aos objetivos específicos do artigo, eles consistem na contextualização do setor sojícula para os três principais produtores/exportadores mundiais do mercado da soja, em revisões de estudos empíricos que abordam o uso dos mesmos recursos metodológicos e na mensuração da competitividade e da concentração das exportações.

Este artigo está estruturado em três seções, além desta Introdução e das Considerações Finais. A segunda seção apresenta a economia mundial da soja, os principais fatores da competitividade no mercado internacional e uma breve exposição de estudos empíricos que utilizam o IVCR para a análise da competitividade no mercado da soja e de outros produtos do agronegócio no Brasil, na Argentina e nos EUA. Na terceira seção, é exposta a metodologia utilizada na pesquisa, que consiste na mensuração da competitividade e do grau de concentração das exportações do complexo soja dos países investigados por meio do Índice de Vantagem Comparativa Revelada (IVCR) e da Razão de Concentração (CR). Já a quarta seção aborda a discussão dos resultados encontrados para a soja in natura e demais subprodutos nos países líderes do mercado da oleaginosa. Por fim, apresentam-se as conclusões do estudo.

\section{ECONOMIA MUNDIAL DA SOJA}

O market share do Brasil, Argentina e EUA dependem de suas competitividades, seja para conquistar novos mercados com a expansão do consumo, seja para aumentar sua participação em 
detrimento de seu concorrente. Como principais fatores de competitividade, têm-se: o preço, a qualidade e a tecnologia adotada em cada região produtora; as condições naturais; a infraestrutura; e, por fim, o papel do Estado no que diz respeito à formulação de políticas agrícolas e/ou de comércio exterior. Esses são apenas alguns elementos que definem o conceito de competitividade, que irá refletir na capacidade de cada país produtor expandir sua participação no mercado mundial.

A próxima subseção traz um panorama da competitividade dos principais exportadores do mercado da soja e derivados a partir das variáveis produção, produtividade e exportações. Além disso, a segunda subseção apresenta estudos empíricos, mostrando a relevância e o crescente enfoque que se dá a esse tema.

\section{I A COMPETITIVIDADE DOS PRINCIPAIS PAÍSES EXPORTADORES DO COMPLEXO SOJA NO MERCADO INTERNACIONAL}

Ferraz et al. (1997) argumentam que a competitividade de um segmento ou produto é expressa pelo seu desempenho, ou seja, sua participação no mercado (market share), e por sua eficiência, que é a capacidade de transformar insumos em produtos com a máxima produtividade. Essa proposição também é corroborada por Silva e Batalha (1999), que consideram a competitividade como a capacidade de um sistema produtivo manter participação no mercado interno e externo de maneira sustentada.

Já Haguenauer (1989) propõe a competitividade como a capacidade de uma indústria, um setor ou um país de produzir mercadorias com padrões de qualidade específicos, requeridos por determinados mercados, utilizando recursos em níveis iguais ou inferiores aos que prevalecem em indústrias, setores ou países semelhantes no resto do mundo, durante determinado período de tempo.
Para Bertrand et al. (2012, p.231),

Vários conceitos têm sido utilizados para análise da competitividade. Dentre outros, destacam-se os conceitos de competitividade macro, de desempenho e, de eficiência. A competitividade macro é vista do ponto de vista da economia de um país como um todo, destacando condições gerais. $\mathrm{O}$ conceito de desempenho, ligado às vantagens comparativas de Balassa, considera o desempenho das exportações, analisando as mudanças na participação nas exportações, para um país, setores ou produtos. A competitividade eficiência é associada a características estruturais, que levam um país a produzir com níveis de eficiência superiores

Portanto, para efeito de análise dos fatores de competitividade, realiza-se uma breve referência deste quesito ao confrontar as condições de cada player na evolução temporal da cultura da soja em grãos no que tange às três principais medidas de competitividade: as parcelas do mercado em valor; a participação na produção agrícola; e a produtividade de cada um dos concorrentes. Vale aqui ressaltar que apesar da intervenção e/ou alterações nas políticas do Estado ou comparações de custos estáticas, acredita-se que a adoção desse conjunto de medidas permite a indicação de tendências que afetam a dinâmica de um mercado altamente competitivo (BERTRAND et al., 2012).

Em resumo, trata-se de buscar indicadores da competitividade brasileira, argentina e estadunidense para o período de análise, que corresponde aos anos de 1995 e de 2010 (Tabela 1).

É possível perceber que os indicadores refletem de forma significativa o aumento da capacidade e, consequentemente, da participação dos países sul-americanos no que se refere ao complexo soja.

Tabela 1: Principais Fatores de Competitividade da Soja em Grãos entre Brasil, Argentina e EUA para os anos de 1995 e de 2010

\begin{tabular}{ccccccccccc}
\hline \multirow{2}{*}{ Países } & \multicolumn{3}{c}{ Produção (mil ton.) } & \multicolumn{3}{c}{ Produtividade (kg/ha) } & \multicolumn{4}{c}{ Exportações (mil US\$) } \\
\cline { 2 - 11 } & 1995 & $\%$ & 2010 & $\%$ & 1995 & 2010 & 1995 & $\%$ & 2010 & $\%$ \\
\hline Brasil & 25.683 & 20,23 & 68.756 & 25,95 & 2.199 & 2.947 & 770.426 & 10,49 & 11.042 .996 & 28,34 \\
Argentina & 12.133 & 9,56 & 52.677 & 19,88 & 2.044 & 2.905 & 535.966 & 7,30 & 4.986 .277 & 12,80 \\
EUA & 59.174 & 46,61 & 90.606 & 34,19 & 2.375 & 2.922 & 5.427 .678 & 73,88 & 18.586 .268 & 47,69 \\
Demais Países & 29.961 & 23,60 & 52.933 & 19,98 & - & - & 612.941 & 8,34 & 4.354 .787 & 11,17 \\
Mundo & 126.950 & 100 & 264.973 & 100 & 2.030 & 2.583 & 7.347 .011 & 100 & 38.970 .328 & 100 \\
\hline
\end{tabular}

Fonte: FAOSTAT (2013). 
A Argentina, por exemplo, mais do que quadruplicou sua produção, alcançando, em 2010, uma participação de 19,88\% em nível mundial. Já o Brasil, passou de 25.683 mil toneladas para 68.756 mil toneladas, representando uma variação de 5,72 pontos percentuais entre os dois anos analisados. Sua participação na produção mundial, em 2010, foi de $25,95 \%$. Por fim, os EUA, mesmo tendo crescido $53 \%$ na produção de grãos no período, apresentaram um recuo na participação mundial, passando de $46,61 \%$, em 1995 , para $34,19 \%$, em 2010. Com relação ao segundo fator de competitividade analisado na Tabela 1, percebe-se que, em 2010, há certa homogeneidade na produtividade dos três países, com leve predominância do Brasil, seguido dos EUA e da Argentina.

Os resultados dos países sul-americanos, em relação ao aumento da produtividade da soja em grãos, decorrem do trabalho de instituições de pesquisa, como a Empresa Brasileira de Pesquisa Agropecuária (EMBRAPA), para o caso do Brasil, e do Instituto Nacional de Tecnología Agropecuaria (INTA) para a Argentina. No caso dos EUA, este papel é realizado pela Agricultural Research Service (ARS), uma das quatro agências de pesquisa vinculada ao Departamento de Agricultura do país. As outras três são: National Institute of Food and Agriculture (NIFA), Economic Research Service(ERS) e National Agricultural Statistics Service (NASS) (ARS, 2013).

Em 2010, o comércio internacional de grãos de soja atingiu US\$ 38.970.328,42 mil, tendo os EUA como o principal exportador (47,69\%). Em comparação ao ano de 1995, é possível observar que os EUA mesmo com um crescimento nas suas exportações em $242 \%$, viu seu market share reduzir em 26,19 pontos percentuais. O Brasil, que ocupa o segundo lugar no ranking, passou de $10,49 \% \mathrm{em}$ 1995, para 28,34\% em 2010. Já a Argentina que no primeiro ano da análise alcançou US\$ 535.966 mil dólares nas exportações do grão, em 2010 viu sua venda crescer $830 \%$, resultando em US\$ 4.986.277 mil dólares. Desse modo, representa o terceiro lugar com uma participação de $12,80 \%$ em 2010 ante 7,30\% em 1995 (FAOSTAT, 2013).

A competitividade no mercado internacional de commodities reflete a influência de muitos fatores diferentes. Em vista disso, os países estão investindo cada vez mais em novas tecnologias e, assim, obtendo resultados significativos na produção da soja, tornando-se mais competitivos e ganhando parcelas de mercado. Como resultado, seus potenciais competitivos, juntamente com o aumento da demanda internacional pelo produto faz com que esta atividade desenvolva, aumen- tando as exportações com o intuito de manter o crescimento de forma sustentada.

\subsection{ESTUDOS EMPÍRICOS SOBRE A COMPETITIVIDADE DO COMPLEXO SOJA NO BRASIL, NA ARGENTINA E NOS EUA}

Nos últimos anos, tem-se percebido o crescimento de pesquisas econômicas acerca da produção e da comercialização da soja, principalmente, nos países da América do Sul, como o Brasil e a Argentina. Isso ocorre devido ao aumento da tendência nas participações brasileira e argentina no mercado mundial da soja e derivados, que, a partir da metade da década de 1990, conseguiram desviar a atenção de compradores que até então só tinham os EUA como principal ofertante. Assim sendo, algumas simetrias entre os dois países têm sido apontadas para fundamentar a forte concorrência, sobretudo mútua, pelas parcelas de mercado, como: as estruturas produtivas agroindustriais, as estratégias empresariais adotadas e as ações institucionais, representadas pelas políticas governamentais (BARBOSA; NOGUEIRA JR., 2007).

Paralelamente a isso, as condições favoráveis vigentes no mercado internacional ditadas pela crescente demanda e/ou a mudança de padrão de consumo do grão contribuiriam para o processo de consolidação desta cultura nos países sul-americanos. Ademais, é bem verdade que Brasil, Argentina e EUA adotaram como estratégia a intensificação das relações comerciais com o resto do mundo uma vez que se trata de um mercado altamente competitivo, como é possível observar nesta subseção.

No estudo de Waquil et al. (2004), realizou-se uma apreciação do comportamento do comércio agrícola brasileiro com a União Europeia (UE) em vista das negociações de um acordo comercial entre esse bloco e o Mercado Comum do Sul (MERCOSUL). Por conseguinte, foram calculados o IVCR e o Índice de Orientação Regional (IOR), no período de 1991 a 2001. Os produtos analisados pelos autores foram: soja e derivados, suco de laranja, fumo, frango, carne bovina, açúcar e café. Ressalta-se que todos estes produtos tiveram, no período da análise, participação superior a $20 \%$ no total das exportações do Brasil, sendo que a soja e derivados, o suco de laranja e o café tiveram maior participação no mercado internacional. Como reflexo ao fato de que o destino de todos os produtos foi a UE, com a exceção do açúcar, os autores evidenciaram que os IVCR's apresentaram valores estáveis e/ou crescentes ao longo da década. Por isso, a proposta de um acordo entre blocos - com o objetivo de reduzir ou eliminar 
barreiras tarifárias e não tarifárias - garantiria, de certo modo, um aumento das exportações com destino a UE.

Já a proposta de Ilha e Souza (2005) teve por objetivo mensurar a evolução das vantagens comparativas da soja e das carnes bovina e de frango do Brasil no mercado internacional bem como verificar a orientação frente ao Acordo de Livre Comércio da América do Norte (NAFTA) e à UE, no período de 1992 a 2002. Para tanto, utilizou-se o IVCR e o IOR. De acordo com o estudo, verificou-se que os valores encontrados foram maiores que a unidade, para todos os anos analisados, demonstrando que o país possui vantagens comparativas reveladas para os três produtos considerados. No que se refere à soja, o índice VCR apresentou os melhores resultados, indicando competitividade brasileira na produção desta commodity. Em 2002, último ano analisado, o índice atingiu 29,93 ante 13,30 em 1992, ou seja, um crescimento de $125,04 \%$. Entretanto, os autores verificaram um recuo para os anos 1995 e $1996 \mathrm{em}$ razão da redução das exportações brasileiras de soja em função da valorização cambial do Plano Real e também do aumento das exportações mundiais deste produto. Os autores ressaltaram que, a partir de 1997, o índice VCR voltou a crescer de forma significativa, apesar da redução constatada no ano de 1999, quando as exportações brasileiras de soja em grãos apresentaram uma sensível redução. Em suma, o resultado (da soja, da carne bovina e de frango) indica que o Brasil possui vantagens comparativas nas exportações diante dos demais países atuantes no mercado internacional.

Com a intensificação do processo de abertura da economia, a partir da década de 1990, as condições de competitividade de diversas mercadorias passaram a variar mais rapidamente. Desse modo, Vicente (2005) construiu indicadores de competitividade para diferentes agregados de mercadorias do agronegócio, no período de 1997 a 2003, com ênfase para o estado de São Paulo. Em suma, a proposta era exemplificar quais grupos de mercadorias do agronegócio que apresentavam possibilidades de inserção no mercado internacional e identificar o IVCR relacionando-as às taxas de cobertura. A metodologia proposta pelo autor foi o IVCR, o Índice de Contribuição ao Saldo Comercial (ICSC) e a taxa de cobertura, ou seja, a razão entre as importações e exportações. Os resultados mostram que o agronegócio brasileiro, do estado de São Paulo e das demais Unidades Federativas (UF's) revelaram vantagens comparativas com índices crescentes no período de 1997 a 2003. Enquanto o estado de São Paulo apresentou-se mais competitivo nos produtos manufaturados, as demais regiões voltaram-se para os produtos básicos. As maiores taxas de cobertura corresponderam aos produtos semimanufaturados, tanto em nível nacional quanto para o estado paulista. Já para as demais UF's, foram os produtos básicos. Para todos os grupos de mercadorias do agronegócio - exceto bens de capital e insumos - os índices foram positivos e com tendência crescente. As exportações do agronegócio de São Paulo apresentaram desvantagens comparativas em relação às brasileiras, menos as manufaturadas, que se mostraram vantajosas em todo o período. Já as taxas de cobertura foram superiores a $1 \mathrm{em}$ praticamente todos os casos, exceto para os produtos básicos em São Paulo, em 1996 e 1998.

Coronel et al. (2007) analisaram a competitividade da soja produzida em Ponta Porã e no Mato Grosso do Sul, sendo verificada através da exportação do produto em nível internacional. Com o intuito de atingir o objetivo, utilizou-se o IVCR, no qual foi possível constatar que nos primeiros anos de análise, 1997 e 1998, o índice ficou abaixo da unidade, o que significa que nessas safras a produção de soja não teve um desempenho competitivo. Tal explicação se deve à crise produtiva desde a safra de 1996, quando a produção sofreu uma queda de 27,29\% em relação ao ano anterior. Além disso, outro fator que pode ter contribuído foi a sobrevalorização cambial do período de 1995 a 1998. Já a partir de 1999 até 2004, o IVCR foi maior que a unidade, revelando vantagens comparativas. Para o estado do Mato Grosso do Sul, verifica-se que todos os valores encontrados foram maiores que a unidade em todo o período de análise.

A pesquisa realizada por Coronel e Dessimon (2007) teve o objetivo de analisar a competitividade das exportações de soja brasileira, no período de 1992 a 2004, bem como a orientação das exportações brasileiras desta commodity. Para tanto, fez-se uso do IVCR e do IOR. Como resultados, constatou-se que tanto a produção quanto as exportações brasileiras de soja aumentaram de forma significativa no período analisado. $\mathrm{O}$ IVCR permitiu identificar que o Brasil apresentou vantagens comparativas reveladas durante os 12 anos estudados, com a exceção de 1995, 1996, 1999 e 2003 . A explicação para a queda nos dois primeiros anos esteve relacionada à sobrevalorização cambial do real no período de 1995 a 1998, ao aumento das exportações mundiais e à queda nas exportações brasileiras. Já para 1999 e 2003, identificou-se o recuo nas exportações brasileiras como fator predominante para a pequena queda no 
índice. De acordo com os autores, as exportações mundiais de soja cresceram proporcionalmente mais que as exportações brasileiras de soja. Os dados revelam que, em 2003, por exemplo, as exportações mundiais tiveram um aumento aproximado de $44,60 \%$, enquanto que a expansão das exportações brasileiras representou apenas $41,50 \%$.

Por fim, os autores ainda concluíram que o Brasil é um país competitivo no que se refere às exportações do complexo soja, contudo, ainda há obstáculos a serem superados para o país aumentar sua participação no mercado internacional. Esses fatores podem ser de ordem interna, tais como maior integração entre os elos da cadeia produtiva e os custos de produção, que recaem, em sua maior parcela, nos problemas logísticos. A deficiência na infraestrutura de transportes, mais especificamente seus sistemas de rodovias, hidrovias e ferrovias, dificulta o escoamento da produção brasileira, uma vez que esta se localiza em regiões centrais do país. Embora empresas privadas estejam investindo em sistemas multimodais, os investimentos permanecem escassos e muito dependentes do setor público, seja em volume de recursos ou em regulamentação da privatização. Entretanto, há também os fatores de ordem externa, como, por exemplo, as barreiras tarifárias e não tarifárias que países importadores impõem no momento da comercialização.

Coronel et al. (2008) analisaram se o Brasil apresenta vantagens comparativas reveladas para as exportações de grão, farelo e óleo de soja e identificaram a orientação regional das exportações de cada uma dessas commodities para os principais mercados consumidores. Os autores adotaram, como metodologia, o cálculo do IVCR e do IOR, para o período de 1995 a 2004. Os resultados indicaram que o país apresenta vantagens comparativas reveladas para a soja e seus derivados e, no que tange à orientação regional, verificou-se que as exportações de grão estão fortemente orientadas para a UE e a China, as do farelo para a UE e a Tailândia e as do óleo para a China, o Irã e a Índia.

Já a pesquisa realizada por Rudell e Prieb (2008) teve a finalidade de avaliar a competitividade da soja em grão brasileira para a China bem como verificar sua orientação regional durante o período de 1995 a 2005. Em um primeiro momento, foi apresentada, de modo exploratório, a inserção do comércio da oleaginosa entre Brasil-China e, posteriormente, efetuou-se o cálculo do IVCR e do IOR. Os resultados revelaram que o Brasil possui vantagens comparativas reveladas nas exportações de soja em grão para a China no período assinalado, sendo todos estes crescentes, com exceção dos anos de 1999, 2001 e 2003, que apresentaram pequenas reduções no IVCR. Os motivos, segundo os autores, podem estar relacionados ao aumento das exportações mundiais do grão e da queda nas exportações brasileiras e, é claro, da valorização cambial. Com relação ao IOR, foi possível demonstrar que as exportações de soja em grão estão sendo direcionadas para o mercado oriental desde 1997, porém não de modo crescente.

O estudo realizado por Silva et al. (2010) teve o objetivo de analisar o padrão da inserção brasileira no mercado internacional de grãos (milho e soja), no período de 1997 a 2008. Para isso, os autores utilizaram o IVCR e o IOR, entre outros métodos estatísticos. Os resultados da pesquisa apresentaram que houve um aumento contínuo das exportações de grãos ao longo da série analisada e que estas se concentraram principalmente na soja. Além disso, verificou-se que o Brasil possui vantagem comparativa na exportação de grãos para todo o período, com destaque para o ano de 2004, quando o Brasil alcançou um IVCR de 4,9. De acordo com os autores, esse valor foi impulsionado principalmente pelo desempenho das exportações de soja. Com relação ao IOR, as exportações de soja apresentaram forte orientação para a UE e a China. Já em relação ao milho, o valor desse índice revelou que as exportações do produto têm a orientação voltada para o Irã e a Coreia do Sul.

Quadro 1 apresenta um resumo dos estudos empíricos analisados, onde são expostos os períodos, as regiões, os produtos e as metodologias empregadas, além dos principais resultados de cada pesquisa.

Estas pesquisas revelam a intensificação do processo de globalização e o intuito de os países terem maior competitividade no contexto econômico internacional. A próxima seção consiste na apresentação das fontes dos dados bem como dos métodos para mensuração da competitividade dos três principais players da soja e seus derivados e da possível concentração nos principais mercados exportadores.

\section{MATERIAL E MÉTODOS}

Nesta seção, apresentam-se as fontes dos dados e os dois métodos utilizados: IVCR e CR.

\subsection{FONTE DOS DADOS}

Além da revisão bibliográfica, a partir da pesquisa ao Portal de Periódicos CAPES, para o desenvolvimento deste estudo também foram consultadas as seguintes instituições para acesso 
às bases de dados: do Brasil, Secretaria do Comércio Exterior, do Ministério do Desenvolvimento, Indústria e Comércio Exterior (SECEX/MDIC); da Argentina, Ministerio de Agricultura, Ganadería y Pesca (MAGyP) e Secretaría de Agricultura, Ganadería, Pesca y Alimentos de la Nación (SAGPyA); e dos EUA, United States Department of Agriculture (USDA). Além disso, foram consultadas as bases de dados FAOSTAT, da Food and Agriculture Organization of the United Nations (FAO), e UNCTAD Statistcs, da United Nations Conference on Trade and Development (UNCTAD).

No cálculo do ICVR e do CR da soja e derivados do Brasil, da Argentina e dos EUA, foram utilizados os dados de valor de exportação (em US\$), disponíveis na United Nations Commodity Trade - Statistics Division (UN COMTRADE). A classificação das mercadorias se deu através do SH6, cuja composição permite que sejam atendidas as especificidades dos produtos, tais como origem, matéria constitutiva e aplicação, em um ordenamento numérico lógico, crescente e de acordo com o nível de sofisticação das mercadorias (MDIC, 2013).

Para o caso da soja, são eles: 120100 Soja mesmo triturada; 120810 - Farinha de soja; 150710 - Óleo de soja, em bruto, mesmo degomado; 150790 - Óleo de soja e respectivas frações, mesmo refinados, mas não quimicamente modificados; e, 230400 - Tortas e outros resíduos sólidos da extração do óleo de soja (Farelo de Soja). A partir dessa classificação, foi possível a mensuração do índice e da medida de concentração, das exportações dos produtos pelos países, para os anos de 1995, pois se refere ao primeiro ano após o término da Rodada do Uruguai, da OMC, e de 2010.

\subsection{METODOLOGIA}

\subsection{I Índice de Vantagem Comparativa ReVelada (IVCR)}

Ao assumir a inviabilidade de mensurar todos os fatores capazes de afetar a competitividade de uma economia, Balassa (1965) entendeu que o desempenho do país é reflexo das suas assimetrias de custos relativos de produção e que, portanto, revela suas vantagens comparativas.

Já Reis e Azevedo (2008, p.7) relatam que:

Através desse índice busca-se medir os produtos nos quais um determinado país "a" produz com maior eficiência em relação ao restante dos países do mundo, baseando-se para isso nos fluxos de comércio passado de um determinado produto "i" em relação à exportação total do país "a". Ou seja, baseia-se no percentual que o produto "i" tem sobre a pauta de exportação do país "a", comparada com a exportação total mundial do produto "i" em relação à exportação total mundial. O índice é matematicamente assim definido: $\operatorname{IVCR}=\left(\mathrm{X}_{\mathrm{ij}} / \mathrm{X}_{\mathrm{i}}\right) /\left(\mathrm{X}_{\mathrm{wj}} / \mathrm{X}_{\mathrm{w}}\right)$.

Onde: $X_{\mathrm{ij}}=$ é o valor das exportações do país i do produto $\mathrm{j} ; \mathrm{X}_{\mathrm{i}}=$ é o valor total das exportações do país $\mathrm{i} ; \mathrm{X}_{\mathrm{wj}}=$ é o valor das exportações mundiais do produto $\mathrm{j} ; \mathrm{X}_{\mathrm{w}}=$ é o valor total das exportações mundiais.

Para valores superiores a um, apresentados pelo índice, pode-se dizer que o país possui vantagem comparativa revelada para as exportações do produto e derivados. Entretanto, se o valor do índice for inferior a um, entende-se que o país não possui vantagem comparativa revelada na exportação do produto estudado. Em suma, quanto mais alto o valor do IVCR, maior será a vantagem comparativa do país naquele produto.

Cabe aqui ressaltar que o IVCR também possui suas limitações, pois o mesmo pressupõe que a medida de competitividade de determinado país seja explicada por meio do seu desempenho no comércio internacional. Desse modo, há possibilidade de equívocos para aqueles casos de produtos que possuem desoneração em alguma alíquota para exportação, subsídios, restrições quantitativas, tarifas de importação etc. Figueiredo e Santos (2005, p. 11) comentam que "essas limitações surgem porque a noção de vantagem comparativa revelada está interligada a fatores estruturais do processo produtivo, sendo associada de forma direta aos custos relativos de produção".

O índice revela, portanto, o nível das exportações de determinado país em relação a sua pauta exportadora, bem como a comparação do bem entre diferentes países. Além disso, permite definir o quão competitivo o país é por consequência do nível de especialização que o mesmo possui em nível internacional e interno.

Já para Kupfer (1993), a competitividade está associada ao desempenho das exportações. Trata-se de um conceito ex-post, que avalia a competitividade por meio de seus efeitos sobre o comércio externo. Segundo Giordano (1999, p.88), a

competitividade é a habilidade de exportar os bens e serviços dentro do tempo, local e formas desejadas pelos compradores, a preços tão bons ou melhores que outros potenciais fornecedores, sendo estes preços suficientes para ao menos remunerar o custo de oportunidade dos recursos empregados.

Por fim, é válido comentar que todas as técnicas de mensuração de competitividade apresentam limitações, devendo a escolha recair naquela mais adequada para a análise pretendida. Este 
índice teve sua escolha por estar sendo amplamente utilizado em estudos de produtos agroalimentares, permitindo, por meio das estatísticas de comércio internacional, as comparações desejadas. Além disso, permite avaliar a (in) evolução da competitividade do setor analisado. Por estas razões, o IVCR foi o indicador de mensuração utilizado nesta pesquisa.

\subsubsection{RAZÃo de Concentração (CR)}

O presente artigo também emprega uma medida de concentração parcial, denominada Razão de Concentração ou $\mathrm{CR}_{\mathrm{k}}$. Essa medida consiste na determinação da parcela de mercado das $\mathrm{k}$ maiores empresas da indústria. No caso dessa pesquisa, a razão de concentração fez referência aos três principais parceiros comerciais, ou seja, $\mathrm{CR}_{3}$, de cada país e por produto, permitindo verificar o quão concentrados são esses fluxos comerciais no mercado internacional.

Neste método, a concentração é definida como o somatório das parcelas de mercado das k-ésimas maiores firmas ou países. Deste modo, tal índice é definido por:

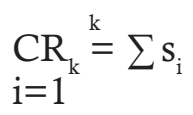

Onde: $\mathrm{s}_{\mathrm{i}}$ é parcela de mercado do i-ésimo país; e k refere-se ao número de países analisados. Quanto maior o valor da medida, mais concentrado será o fluxo comercial exercido pelas $\mathrm{k}$ maiores nações.

Apesar de ser uma medida amplamente empregada, existem algumas críticas feitas ao seu uso, como apontadas por Koch (1980):

As taxas de concentração não descrevem o número total e a distribuição de tamanho dos países;

As taxas de concentração não dão informação sobre o tamanho relativo e sobre a posição do grupo de países incluídas na taxa. A consequência, conforme revela Martin (1993), é que diferentes estruturas podem originar as mesmas taxas de concentração;

As taxas de concentração não refletem a presença ou ausência de concorrentes potenciais;

As taxas de concentração da produção doméstica ignoram o papel das importações nos mercados domésticos, o que superestima o poder de mercado dos países locais, assim como das exportações dos produtores domésticos, o que pode subestimar o poder dos países que participam do mercado externo; e

As taxas de concentração não refletem as mudanças de posição das nações.

Além disso, algumas limitações podem surgir com a utilização dessa medida, pois um $\mathrm{CR}_{3}$ de $30 \%$ pode representar três países com $10 \%$ cada um ou também há possibilidade de que uma nação tenha participação maior, como $28 \%$, enquanto as demais participem apenas com $1 \%$, cada uma, do mercado. Em outras palavras, a limitação consiste na possibilidade dos países apresentarem participações com um grau muito elevado de diferenciação entre si.

Por fim, Farina (1993) lembra que o conceito de concentração não se refere apenas ao número de participantes de um dado mercado. Mais do que isto, refere-se ao controle de uma grande proporção de uma determinada atividade econômica por uma pequena proporção dos participantes nesta atividade.

A próxima seção apresenta os resultados da mensuração da competitividade e do grau de concentração das exportações do Brasil, da Argentina e dos EUA no que se refere aos mercados da soja mesmo triturada e de seus quatro derivados, a saber: o óleo de soja bruto e óleo de soja fracionado, a farinha de soja e o farelo de soja.

\section{ANÁLISE E DISCUSSÃO DOS RESULTA- DOS}

Esta seção apresenta o grau de concentração e a competitividade das exportações do complexo soja do Brasil, da Argentina e dos EUA, no período 1995 e 2010.

\section{I GRAU DE CONCENTRAÇÃO DO COMPLEXO SOJA}

Para permitir uma avaliação da evolução da concentração dos principais mercados consumidores da soja e derivados produzidos pelo Brasil, pela Argentina e pelos EUA, esta subseção apresenta a $\mathrm{CR}_{3}$ para os anos de 1995 e de 2010. As próximas subseções têm a finalidade de analisar os dados de forma desagregada, ou seja, descrever quais os principais parceiros comerciais dos países investigados, por produto, e a (in) evolução de suas respectivas parcelas de mercado, nos dois períodos propostos neste estudo.

\section{I.I BRASIL}

No que se refere à participação da produção mundial de soja, a produção brasileira apresentou um crescimento de $168 \%$ durante o período 1995 2010, ou seja, passou dos 25.682 milhões de tone- 
Tabela 2: Índice $\mathrm{CR}_{3}$ das Exportações do Complexo Soja do Brasil para os Anos de 1995 e 2010

\begin{tabular}{ccccc}
\hline & \multicolumn{2}{c}{ Brasil } & & \multicolumn{2}{c}{2010} \\
& Países & $\%$ & Países & $\%$ \\
\hline \multirow{3}{*}{ Farinha de Soja } & Cuba & 93,67 & Uruguai & 53,93 \\
& Argentina & 2,84 & Portugal & 39,60 \\
$\mathbf{C R}_{3}$ & Nova Zelândia & 2,83 & EUA & 4,31 \\
& & $\mathbf{9 9 , 3 4}$ & & $\mathbf{9 7 , 8 4}$ \\
Óleo de Soja Fracionado & China & 38,35 & Cuba & 29,27 \\
& Hong Kong & 26,02 & França & 6,78 \\
$\mathbf{C R}_{3}$ & Índia & 14,27 & África do Sul & 6,65 \\
& & & $\mathbf{4 2 , 6 9}$ \\
Óleo de Soja Bruto & China & 53,43 & China & 65,59 \\
& Irã & 11,43 & Irã & 6,88 \\
$\mathbf{C R}_{3}$ & Bangladesh & 9,28 & Argélia & 6,41 \\
& & $\mathbf{7 4 , 1 4}$ & & $\mathbf{7 8 , 8 8}$ \\
Soja mesmo Triturada & Holanda & 49,78 & China & 64,60 \\
& Espanha & 14,53 & Espanha & 6,70 \\
$\mathbf{C R}_{3}$ & Japão & 9,05 & Holanda & 4,99 \\
Farelo de Soja & Holanda & $\mathbf{7 3 , 3 6}$ & Holanda & $\mathbf{7 6 , 2 9}$ \\
& Espanha & 10,63 & França & 16,73 \\
$\mathbf{C R}_{\mathbf{3}}$ & França & 8,30 & Tailândia & 9,93 \\
& & & $\mathbf{5 2 , 3 4}$ \\
\hline
\end{tabular}

Fonte: Elaboração própria a partir de UN COMTRADE (2013).

ladas, em 1995, para 68.756 milhões de toneladas, em 2010 (FAOSTAT, 2013). Tal crescimento está relacionado ao deslocamento da cultura pra o Centro-Oeste, que ocorreu devido aos preços mais baixos de terra bem como pelo desenvolvimento de tecnologia para cultivo nos cerrados.

Aliado a este fato, torna-se importante observar que as exportações brasileiras de soja em grão estão isentas do Imposto de Circulação de Mercadorias e Serviços (ICMS), desde que entrou em vigor a Lei Complementar $n^{\circ} 87$, de 13 de setembro de 1996. Seguramente, o incentivo fiscal buscava estimular os setores produtivos voltados ao mercado externo, o que favoreceu o saldo da balança comercial. Entretanto, a Lei Kandir causou (e ainda causa) perdas significativas no que se refere à arrecadação de impostos estaduais, apesar de que o governo federal ficou comprometido em compensar os eventuais prejuízos. Mas as regras para que isso ocorresse não ficaram tão claras de forma que o impasse sobre este assunto segue até o presente momento (ALBUQUERQUE et al., 2010).

Já os demais itens derivados da soja são tarifados em $12 \%$. Essa diferenciação penaliza a competitividade das exportações desses produtos. Como resultado, desde o início da década de 2000, o comércio do grão tem sido maior do que os derivados. A escalada tarifária praticada por outros países, principalmente a China, que protege as atividades de esmagamento, comentado anteriormente, também contribuiu para o pior desempenho do farelo, da farinha e do óleo de soja (BATALHA et al., 2009).

Nestes termos, a Tabela 2 indica os resultados das estimativas feitas através da $\mathrm{CR}_{3}$ para as exportações do complexo soja do Brasil para os anos de 1995 e 2010. Essa representação fortalece a ideia da manutenção de um mercado ainda bastante concentrado para alguns segmentos e outros com relativa queda de pouca magnitude.

Com relação aos destinos da soja e de seus subprodutos no mercado internacional, apenas dois deles tiveram sua concentração elevada ao passo que os outros três tiveram decréscimo em relação aos valores apresentados entre 1995 e 2010. A análise inicial dá-se em relação ao óleo de soja bruto, que teve um incremento quase 5 pontos percentuais na centralização das vendas para o exterior, passando do patamar de $74,14 \%$, 1995, para 78,88\%, em 2010. Cabe inicialmente destacar o desempenho da China, que teve uma maior participação no consumo do produto ofer- 
tado. Assim, considerando o período analisado, o país asiático apresentou um incremento de 12,16 pontos percentuais em suas compras do produto brasileiro. Já os outros dois parceiros comerciais representaram $13,29 \%$, em 2010 , sendo que o Irã possuía $6,88 \%$ e a Argélia $6,41 \%$ dos fluxos comerciais de óleo de soja bruto. Em 1995, os demais países eram Irã, que manteve a segunda posição, mas com uma participação de 11,43\%, e Bangladesch aparecia na terceira posição, com 9,28\%.

No tocante aos índices de concentração, o segundo produto com maior concentração foi a soja mesmo triturada, com ampliação de 2,93 pontos percentuais no período. Seus principais importadores foram a China e a UE, que responderam por cerca de três quartos das exportações brasileiras, em 2010. Deste modo, se tem as seguintes colocações: China, com 64,60\%; Espanha, ocupando o segundo lugar, com $6,70 \%$; e a Holanda, importando $4,99 \%$ do total comercializado pelo Brasil. Em 1995, a Espanha também fazia parte da composição dos três principais destinos, com $14,53 \%$ do valor exportado. Os outros dois eram a Holanda, na primeira posição, com $49,78 \%$, e o Japão, na terceira, com 9,05\%.

O terceiro produto a ser analisado é o óleo de soja em frações. A década de 1990 caracterizou-se por ter sido marcada como um mercado bastante centralizado, uma vez que indicava $78,64 \%$ das exportações para os três primeiros países. No entanto, esse índice registrou um decréscimo na concentração em 35,95 pontos percentuais. Ou seja, desse total revelado para 1995, a China surgia em primeiro lugar no ranking, com $38,35 \%$, seguida de Hong Kong, com $26,02 \%$, e Índia, com 14,27\%. Em 2010, a concentração dos três principais mercados importadores do óleo de soja em frações do Brasil passou para 42,69\%. Entretanto, as vendas seguiram basicamente para Cuba uma vez que representou $29,27 \%$, sendo que os outros $13,42 \%$ ficaram igualmente divididos entre França e África do Sul.

Para completar a análise, as exportações da farinha de soja apresentaram uma redução expressiva entre 1995 e 2010 , passando de US\$ 730 mil para US\$ 35 mil (UN COMTRADE, 2013). O comércio para o último ano pesquisado representou aproximadamente $5 \%$ do que o Brasil vendeu em 1995. Se antes o destino do produto era de $93,67 \%$ para o mercado de Cuba, em 2010, representou $53,93 \%$ para o Uruguai. A segunda colocação passou a ser de Portugal, com 39,60\%, ante $2,84 \%$ da Argentina, em 1995. Por fim, os EUA contribuíram com $4,31 \%$, lugar que já foi ocupado pela Nova Zelândia, com 2,83\%. Desse modo, observa-se que a medida de concentração caiu de $99,34 \%$ para $97,84 \%$, do primeiro para o último ano analisado.

Em 2010, o Brasil dobrou as vendas de farelo de soja, atingindo cerca de US\$ 4.719.373,24 mil (UN COMTRADE, 2013). O principal importador continuou sendo a Holanda, reduzindo sua participação de $39,50 \%$ para $25,68 \%$, entre 1995 e 2010. Observa-se também, em 2010, que o segmento é bastante fragmentado, pois a França possuía $16,73 \%$ e ocupava o segundo principal destino deste item. Já a Tailândia foi responsável por $9,93 \%$ do valor exportado pelo Brasil. Vale lembrar aqui que, em 1995, o país francês assegurava a terceira posição, com $8,30 \%$ enquanto que a Espanha mantinha o segundo lugar, com 10,63\%. Apesar da elevada produtividade e dos baixos custos da terra nas áreas novas do Centro-Oeste e do Nordeste, o Brasil apresenta os maiores custos diretos da produção em relação às demais potências, EUA e Argentina. Os itens de maior impacto no custo de produção são os fertilizantes e os defensivos agrícolas. Além disso, o país enfrenta grandes problemas de logística de distribuição em função da expansão do cultivo para a região central. Portanto, algumas ações poderiam melhorar a competitividade brasileira no mercado internacional da oleaginosa, como: aumento de investimentos em infraestrutura de transportes e armazenamento, $\mathrm{P} \& \mathrm{D}$ para desenvolver novas tecnologias com o intuito de atender novas demandas de mercado, e, por fim, uma reforma tributária com o intuito de discutir e rever o motivo pelo qual o país beneficia a exportação de produtos primários (como a soja em grãos) e penaliza aqueles com maior valor agregado, como o óleo e o farelo de soja (BATALHA et al., 2009).

Com relação aos três principais mercados consumidores das exportações brasileiras entre 1995 e 2010, observa-se um movimento de desconcentração. Revelou-se tal tendência com o óleo fracionado, cujo item apresentou maior queda, com 35,95 pontos percentuais. A segunda queda mais significativa foi a do farelo de soja, com 6,09 pontos percentuais, seguido da farinha de soja, com apenas 1,5 ponto percentual.

Por outro lado, a soja mesmo triturada expôs um aumento no grau de concentração. Se, em 1995, o total dos três principais destinos das exportações era de $73,36 \%$, em 2010 , esse valor foi de $76,29 \%$. Só a China abrange um pouco mais do que $60 \%$ do valor exportado para o mercado internacional, em 2010. Por fim, o óleo de soja bruto, que teve um acréscimo de 4,74 pontos percentuais entre os quinze anos analisados neste 
Tabela 3: Índice CR3 das Exportações do Complexo Soja da Argentina para os Anos de 1995 e 2010

\begin{tabular}{|c|c|c|c|c|}
\hline \multirow{3}{*}{ Produtos / Anos } & \multicolumn{2}{|c|}{ Argentina } & \multirow{2}{*}{\multicolumn{2}{|c|}{2010}} \\
\hline & 19 & & & \\
\hline & Países & $\%$ & Países & $\%$ \\
\hline \multirow{3}{*}{ Farinha de Soja } & Paraguai & 69,70 & EUA & 74,36 \\
\hline & Uruguai & 30,30 & Holanda & 23,56 \\
\hline & EUA & 0,00 & Grécia & 2,08 \\
\hline \multirow[t]{2}{*}{$\mathbf{C R}_{3}$} & & 100,00 & & 100,00 \\
\hline & Chile & 38,90 & África do Sul & 29,57 \\
\hline \multirow[t]{2}{*}{ Óleo de Soja Fracionado } & Nova Zelândia & 17,97 & Angola & 19,37 \\
\hline & Líbano & 10,36 & Haiti & 12,21 \\
\hline $\mathbf{C R}_{3}$ & Venezuela & $\begin{array}{l}\mathbf{6 7 , 2 3} \\
14,93\end{array}$ & Índia & $\begin{array}{l}\mathbf{6 1 , 1 5} \\
28,98\end{array}$ \\
\hline \multirow[t]{2}{*}{ Óleo de Soja Bruto } & Irã & 14,13 & Irã & 10,54 \\
\hline & Bangladesh & 8,92 & Egito & 6,33 \\
\hline \multirow{2}{*}{$\mathbf{C R}_{3}$} & & 37,97 & & 45,84 \\
\hline & Holanda & 33,30 & China & 82,58 \\
\hline \multirow[t]{2}{*}{ Soja mesmo Triturada } & Espanha & 13,09 & Egito & 5,12 \\
\hline & Itália & 10,41 & Irã & 2,10 \\
\hline \multirow[t]{2}{*}{$\mathbf{C R}_{3}$} & & 56,80 & & 89,80 \\
\hline & Holanda & 17,32 & Holanda & 11,29 \\
\hline Farelo de Soja & Itália & 16,89 & Itália & 7,80 \\
\hline $\mathbf{C R}_{2}$ & Dinamarca & $\begin{array}{r}8,83 \\
\mathbf{4 3 , 0 4}\end{array}$ & Indonésia & $\begin{array}{r}7,37 \\
\mathbf{2 6 , 4 7}\end{array}$ \\
\hline
\end{tabular}

Fonte: Elaboração própria a partir de UN COMTRADE (2013).

estudo. Além disso, manteve dois dos três principais parceiros comerciais (China e Irã) durante esse tempo, alterando apenas a Argélia no lugar de Bangladesh.

\section{I.2 ARgentina}

A soja é a principal commodity agrícola da Argentina, tendo grande importância econômica para o país. De acordo com MAGyP (2013), a produção encontra-se em 13 estados, embora a maior parte concentre-se na região pampeana. A difusão de sementes transgênicas e do plantio direto permitiu expandir a produção por quase todo o país. A cultura da soja na Argentina é quase a metade da destinada a todos os cultivos de cereais e oleaginosas. No entanto, as províncias de Córdoba, Santa Fé e Buenos Aires concentram ainda $70 \%$ da área plantada, seguidas por Entre Ríos e estados da região norte e noroeste.

A Tabela 3 apresenta os três principais mercados para os quais a Argentina exporta bem como o grau de participação individual e em conjunto $\left(\mathrm{CR}_{3}\right)$, para cada produto do complexo soja, nos anos de 1995 e 2010.

Quanto a $\mathrm{CR}_{3}$, o país só teve aumento em dois produtos. $\mathrm{O}$ maior deles foi a soja mesmo triturada, que teve sua concentração alterada de
$56,80 \%$ para $89,80 \%$, ou seja, uma diferença de 33 pontos percentuais, em quinze anos. Observa-se que para o primeiro ano analisado, a concentração não era tão elevada uma vez que a Holanda detinha $33,30 \%$, enquanto que a Espanha representava $13,09 \%$ e a Itália, na terceira colocação, possuía $10,41 \%$. Já em 2010, a China ocupou o primeiro lugar como principal mercado importador do país portenho, representando $82,58 \%$, seguida por Egito, com 5,12\%, e Irã, com 2,10\%. Vale destacar que o comércio de grãos concentra-se particularmente em países que possuem uma indústria de esmagamento consolidada, geralmente protegida por tarifas de importação mais elevadas para os derivados, como é o caso da China e outros países da Europa. De acordo com a Bolsa de Comércio de Rosário (2013), os impostos de exportação têm as seguintes alíquotas: a incidência mais elevada é direcionada para o grão, com $35 \%$, enquanto que o farelo, a farinha e o óleo bruto ou refinado registram a alíquota de $32 \%$.

Conforme MAGyP (2013), a indústria de óleo na Argentina destina ao mercado mundial mais de $95 \%$ da sua produção. Definitivamente, a produção, seja de grão seja de óleo e/ou farelo, é exportada quase em sua totalidade. Assim, pode-se dizer que a Argentina é o único dos grandes 
produtores com um consumo interno muito baixo.

No período analisado, o segundo produto que teve acréscimo no grau de concentração foi o óleo de soja bruto. A Índia foi o destino de $28,98 \%$ das exportações em 2010. Irã e Egito somaram os outros 16,87\%, do total de 45,84\%. Entre 1995 e 2010, houve a ampliação da concentração em 7,87 pontos percentuais. É importante ressaltar que o Irã manteve a mesma colocação nos dois anos analisados, ou seja, aumentou sua importação de US\$ 131 milhões para US\$ 417 milhões, porém reduziu sua representatividade de $14,13 \%$ para $10,54 \%$. Já a primeira e a terceira colocações no ranking eram ocupadas pela Venezuela, com $14,93 \%$ e, Bangladesh, com $8,92 \%$ respectivamente.

Para os demais produtos, tiveram o grau de concentração inalterado, como é o caso da farinha de soja, que foi exportada, em 2010, para apenas três países em todo o mundo, a saber: EUA, Holanda e Grécia, com 74,36\%, 23,56\% e 2,08\%, respectivamente. Entretanto, verifica-se que, em 1995, a concentração era ainda mais expressiva por dois motivos. Além de o mercado ter como destino dois países, os mesmos estão localizados no mesmo continente, ou seja, a América do Sul. O Paraguai ocupava a primeira posição com $69,70 \%$ do valor exportado, seguido do Uruguai, com a $30,30 \%$. Ou apresentaram reduções significativas, como, por exemplo, farelo de soja. Esse produto, que teve suas vendas ampliadas em 701,66\%, de 1995 para 2010, sustentou os mesmos parceiros comerciais, exceto o terceiro maior, que passou a ser a Indonésia, com 7,37\%, ao invés da Dinamarca (que representava 8,83\%). Os dois primeiros, pela ordem, foram: Holanda, com $11,29 \%$ do total exportado pela Argentina, e Itália, com 7,80\%. Juntos, representam $26,47 \%$ ante $43,04 \%$, em meados da década de 1990. Em outras palavras, um decréscimo de 16,57 pontos percentuais.

Por fim, o destino do óleo de soja fracionado argentino para os três principais mercados importadores apresentou uma redução moderada na concentração uma vez que passou de $67,23 \%$, em 1995, para $61,15 \%$, em 2010. Para o último ano

Tabela 4: Índice CR3 das Exportações do Complexo Soja dos EUA para os Anos de 1995 e 2010

\begin{tabular}{|c|c|c|c|c|}
\hline \multicolumn{5}{|c|}{ Estados Unidos da América } \\
\hline \multirow{2}{*}{ Produtos / Anos } & \multicolumn{2}{|c|}{1995} & \multicolumn{2}{|c|}{2010} \\
\hline & Países & $\%$ & Países & $\%$ \\
\hline \multirow{3}{*}{ Farinha de Soja } & México & 24,90 & México & 39,07 \\
\hline & Japão & 21,88 & Filipinas & 17,29 \\
\hline & Filipinas & 21,29 & Japão & 15,89 \\
\hline \multirow[t]{2}{*}{$\mathbf{C R}_{3}$} & & 68,06 & & 72,25 \\
\hline & China & 18,83 & México & 23,49 \\
\hline \multirow[t]{2}{*}{ Óleo de Soja Fracionado } & Haiti & 14,06 & Canadá & 22,70 \\
\hline & Índia & 11,68 & Cuba & 9,83 \\
\hline \multirow[t]{2}{*}{$\mathrm{CR}_{3}$} & & 44,58 & & 56,02 \\
\hline & China & 64,71 & China & 28,81 \\
\hline \multirow[t]{2}{*}{ Óleo de Soja Bruto } & México & 7,62 & Marrocos & 14,44 \\
\hline & Rep. da Coréia & 3,77 & México & 11,16 \\
\hline \multirow[t]{2}{*}{$\mathbf{C R}_{3}$} & & 76,10 & & 54,41 \\
\hline & Japão & 18,15 & China & 58,22 \\
\hline \multirow[t]{2}{*}{ Soja mesmo Triturada } & Holanda & 15,57 & México & 8,04 \\
\hline & China & 11,06 & Japão & 6,07 \\
\hline \multirow[t]{2}{*}{$\mathbf{C R}_{3}$} & & 44,78 & & 72,33 \\
\hline & Canadá & 16,05 & Canadá & 11,42 \\
\hline \multirow[t]{2}{*}{ Farelo de Soja } & Filipinas & 12,29 & México & 11,09 \\
\hline & México & 7,35 & Filipinas & 8,25 \\
\hline $\mathbf{C R}_{3}$ & & 35,68 & & 30,76 \\
\hline
\end{tabular}

Fonte: Elaboração própria a partir de UN COMTRADE (2013). 
estudado, a última posição foi ocupada pelo Haiti, com 12,21\%, seguido de Angola, com 19,37\%, e África do Sul, com 29,57\% do total exportado pela Argentina. Já em 1995, o principal parceiro portenho era o Chile, com 38,90\%. A Nova Zelândia ocupava o segundo lugar no ranking, com 17,97\%, seguido pelo Líbano, com 10,36\%.

Em resumo, a análise geral da participação de cada produto do complexo soja mostra que a soja mesmo triturada e o óleo de soja bruto apresentaram maiores índices de concentração nos três principais mercados consumidores. No caso da farinha de soja, embora tenha tido alteração apenas nos parceiros comerciais que, passaram a ser os EUA, a Holanda e a Grécia, em 2010, ao invés do Paraguai e do Uruguai, em 1995, o índice que representa o grau de concentração dos principais destinos por valor exportado se manteve em $100 \%$ nas duas oportunidades.

O oposto é observado para as exportações portenha do óleo fracionado bem como do farelo de soja, dos quais têm grande representatividade no comércio internacional. A desconcentração, entre os dois anos estudado, equivale à redução de 6,08 pontos percentuais no óleo, enquanto que o farelo teve um recuo mais significativo, ou seja, de 16,57 pontos percentuais.

\subsubsection{EUA}

Os EUA foram os pioneiros na produção e na comercialização de soja em grãos e seus derivados na década de 1960, sendo, até a safra $2010 / 2011$, os maiores produtores mundiais. Segundo Moro e Lemos (1999), Brum (2002) e Senna e Mello (2008), o país apresenta vantagens tanto na produção quanto na comercialização da oleaginosa uma vez que possui menores custos no cultivo e armazenamento do produto, maiores investimentos em P\&D e uma infraestrutura adequada para a operação como um todo.

A Tabela 4 mostra os resultados do índice $\mathrm{CR}_{3}$ das exportações do complexo soja dos EUA, para os anos de 1995 e de 2010. Os dados permitem identificar o quão cada país representa individualmente e, consequentemente, o quanto os três principais mercados do país estadunidense representam em cada segmento da soja in natura, que neste trabalho denomina-se como soja mesmo triturada, e os demais derivados.

Os fluxos comerciais tiveram suas razões de concentração ampliadas no que se refere à soja mesmo triturada e ao óleo fracionado. No primeiro, o índice apresentou uma elevação de 27,54 pontos percentuais, passando dos $44,78 \%$ para $72,33 \%$, em 2010. A China permaneceu sendo o principal parceiro, respondendo por $58,22 \%$ das vendas estadunidenses, em 2010. A segunda colocação foi do México, que pertence ao mesmo bloco econômico, com $8,04 \%$. Japão ocupou a terceira posição, com $6,07 \%$. Nota-se que a participação do México como destino das exportações do país deste e de outros itens pesquisados neste estudo, converge no sentido de promover a cooperação efetiva entre os países. Tal integração é alicerçada através do NAFTA, que envolve os seguintes países: Canadá, México e EUA. O bloco é considerado como uma zona de livre comércio, ou seja, um grupo de países que concordou em eliminar as tarifas, quotas e barreiras alfandegárias e comerciais que recaem sobre a maior parte dos bens importados e exportados entre estes países, tendo como principal objetivo estimular as transferências intrabloco.

Além da soja mesmo triturada, outro produto que também teve a comercialização mais centralizada, mesmo que em menor proporção, foi o óleo de soja em frações. Neste segmento, em 2010, o primeiro lugar foi ocupado pelo México, com $23,49 \%$, seguido pelo Canadá, com $22,70 \%$. Cuba tomou a terceira posição, com $9,83 \%$, que antes era ocupada pela India. Este mercado apresentou um acréscimo de 11,45 pontos percentuais nos quinze anos analisados.

O óleo de soja bruto, que possuía alta concentração entre os três principais mercados em 1995 , com $76,10 \%$, teve, em 2010, uma queda do índice para $54,41 \%$. Em 1995 , a comercialização deste produto era concentrada na China, que tinha uma participação de $64,71 \%$, sendo os outros $11,39 \%$ divididos entre México, com 7,62\%, e Coréia do Sul, com 3,77\%. Já para o último período da pesquisa, a participação da China reduziu para $28,81 \%$. Marrocos surgiu como o segundo maior parceiro, respondendo por uma parcela de $14,44 \%$ das exportações estadunidenses de óleo de soja bruto. O México, por sua vez, ficou com $11,16 \%$.

Quanto aos dois últimos subprodutos da soja, inicia-se a análise pela farinha, que permaneceu com os mesmos parceiros comerciais nos dois anos estudados, mudando apenas as participações de cada um. Em 1995, as vendas tinham uma concentração de $68,06 \%$, porém bem distribuídas entre México, Japão e Filipinas, com 24,90\%, $21,88 \%$ e $21,29 \%$, respectivamente. Em 2010, o México aumentou sua participação para 39,07\%. Com relação aos outros dois, houve uma inversão nas posições. Filipinas, que se localiza no sudeste asiático, passou a ser o segundo maior mercado de exportação deste produto, com 17,29\%, e Japão 
Tabela 5: IVCR do Complexo Soja para Brasil, Argentina e EUA para os Anos de 1995 e 2010

\begin{tabular}{lcccccc}
\hline \multirow{2}{*}{ Países / Produtos / Anos } & \multicolumn{2}{c}{ Argentina } & \multicolumn{2}{c}{ Brasil } & \multicolumn{2}{c}{$\begin{array}{c}\text { Estados Unidos da } \\
\text { América }\end{array}$} \\
\cline { 2 - 7 } & 1995 & 2010 & 1995 & 2010 & 1995 & 2010 \\
\hline Farinha de Soja & 0,08 & 0,25 & 0,67 & 0,004 & 1,95 & 6,59 \\
Óleo de Soja Frações & 4,43 & 23,44 & 2,83 & 7,10 & 2,33 & 1,43 \\
Óleo de Soja Bruto & 72,83 & 111,59 & 36,50 & 11,38 & 1,30 & 2,07 \\
Soja mesmo Triturada & 17,83 & 28,42 & 11,55 & 21,35 & 6,47 & 5,68 \\
Farelo de Soja & 42,24 & 82,80 & 37,25 & 16,18 & 1,46 & 1,68 \\
\hline
\end{tabular}

Fonte: Elaboração própria a partir de UN COMTRADE (2013).

assumiu a terceira colocação, com $15,89 \%$.

O mesmo aconteceu com o farelo de soja. No entanto, ao invés do Japão, foi o Canadá que entrou no seleto grupo das principais rotas de destino das exportações estadunidenses. O Canadá permaneceu na mesma posição, ou seja, em primeiro lugar, mesmo tendo sua participação reduzida em 4,63 pontos percentuais, passando de $16,05 \%$, em 1995 , para $11,42 \%$, em 2010 . Filipinas e México, que representavam, em 1995, 12,29\% e $7,35 \%$, respectivamente, em 2010 , inverteram a ordem e, assim, México se estabeleceu na segunda posição, com 11,09\%, e Filipinas, com 8,25\%.

Para concluir, os resultados da $\mathrm{CR}_{3}$ apontam para algumas conclusões que cabem aqui ressaltar. O Brasil teve a desconcentração do óleo de soja fracionado como resultado mais expressivo uma vez que apresentou uma diminuição no patamar de 35,95 pontos percentuais, entre 1995 e 2010. O oposto vale para o óleo de soja bruto, com aumento de 4,74pontos percentuais, e a soja mesmo triturada, que mostrou um aumento de 2,93 pontos percentuais. No caso da Argentina, vale lembrar que apenas dois produtos dos cinco estudados tiveram aumento na concentração entre os três principais parceiros comerciais. O primeiro item foi a soja mesmo triturada, que representou uma elevação de 33 pontos percentuais entre 1995 e 2010, seguido do óleo de soja bruto, com 7,87 pontos percentuais, para o mesmo período analisado. Já com relação à queda na concentração nos principais destinos das exportações portenha, aponta-se o farelo de soja, com 16,57 pontos percentuais. Por fim, estão os EUA, que exibiram a soja mesmo triturada como o produto com maior ampliação do índice de concentração entre os dois anos propostos na pesquisa. Tal fato representa um crescimento de 27,54 pontos percentuais, seguido do óleo de soja mesmo fracionado, que elevou em 11,45 pontos percentuais a concentração dos três principais países.

A próxima subseção tem a finalidade de analisar os resultados do IVCR para mensurar o quão competitivo cada país é na exportação nos cinco produtos desse segmento do agronegócio.

\subsection{VANTAGENS COMPARATIVAS REVELADAS E COMPETITIVIDADE DAS EXPORTAÇÔES DE SOJA E DERIVADOS}

Os resultados apresentados na Tabela 5 ilustram, por meio da mensuração do IVCR, as vantagens comparativas reveladas dos três principais países produtores/exportadores - Argentina, Brasil e EUA - da oleaginosa e de seus derivados, para os anos de 1995 e de 2010.

Nas subseções a seguir são analisadas as vantagens comparativas desses países, por produto, nos anos de 1995 e de 2010.

\subsection{FARINHA DE SOJA}

De acordo com a Tabela 5, verifica-se que os valores obtidos revelam que em apenas um produto e dois países, no caso Brasil e Argentina, o IVCR foi inferior a 1 , ou seja, revelando que ambos os países não possuem competitividade relativa nas exportações da farinha de soja. Para os dois períodos estudados, a Argentina, mesmo tendo evidenciado aumento no índice, passando de 0,08 , em 1995 , para 0,25 , em 2010, possui o valor abaixo de uma unidade, o que mostra que o país não possui competitividade neste produto. A mesma linha de raciocínio vale para o Brasil, que exportou, no último ano pesquisado, apenas US\$ 35.602 mil ante US\$ 730.668 mil, em 1995. Ou seja, apenas $4,87 \%$ do que foi exportado na metade da década de 1990. Essa redução indica que as exportações brasileiras de farinha de soja vêm perdendo espaço no comércio mundial, fazendo com que o índice atingisse apenas 0,004, em 2010.

Já os EUA mostram unidades maiores do 
que 1 para os dois anos pesquisados, revelando maior competitividade relativa do que os países da América do Sul. Este comportamento ocorre pelo fato de suas exportações terem um crescimento relativamente maior do que as exportações mundiais. Em números percentuais, verifica-se que o país estadunidense exportou, em 2010, US\$ 408.171,81 mil ante US\$26.705,69, em 1995, ou seja, um aumento de $1.428 \%$. Já as exportações mundiais apresentaram um crescimento de $514 \%$, passando de US\$ $120.137,35$ mil para US\$ 737.416,28 mil.

\subsection{2 Óleo de Soja Frações}

No caso da indústria de processamento, observa-se que os três países analisados apresentam valores maior do que um para o óleo de soja fracionado entre os dois períodos estudados. Isso significa que todos possuem vantagem comparativa revelada para este produto. No entanto, na comparação entre a composição das exportações, fica patente entre os três países o perfil exportador por parte da Argentina. Isso pode ser justificado pelo aumento de $1.042 \%$ do valor exportado de 1995 para 2010, passando de US\$ $15.449,24$ mil para US\$ $176.428,96$. Atrelado a isso, em princípio, está o fato também do país portenho possuir um baixo consumo doméstico bem como a influência da estrutura tributária, que incentiva o comércio exterior dos derivados da soja ao invés da soja mesmo triturada.

O Brasil segue a mesma tendência da Argentina ao elevar o seu índice de 2,83, em 1995, para 7,10 , em 2010. Essa maior competitividade relativa mostra que as exportações brasileiras do óleo fracionado cresceram proporcionalmente mais que as exportações mundiais. Com relação aos EUA, mesmo havendo uma redução do IVCR entre os dois anos propostos para análise, o país ainda mantém sua competitividade neste derivado da oleaginosa. A queda do índice de 2,33 para 1,43 revela que o país exportou menos que a média praticada mundialmente. Ou seja, enquanto o mundo elevou em $96 \%$ o valor exportado, passando de US\$ 851.436,65 mil para US\$1.671.597,58 mil, os EUA apresentaram uma redução em 11,52\% ao atingir US\$ 200.060,61 mil, em 2010, ante US\$ 226.115,77 mil, em 1995 (UN COMTRADE, 2013). 4.2.3 Óleo de Soja Bruto

Os resultados do IVCR para o óleo de soja bruto corroboram com os encontrados por Waquil et al. (2004). Segundo esses autores, a queda brasileira representada pelo índice de vantagens comparativas reveladas - de 36,50 para 11,38 - pode estar relacionada com a implantação da Lei Kandir, em 1996. A influência dessa nova estrutura tributária, que desonerou as exportações do grão, fez com que os exportadores privilegiassem as exportações da soja mesmo triturada em detrimento do processamento interno. Ademais, outro fator que contribuiu foi a sobrevalorização cambial do ano de 2010, que iniciou a uma taxa R\$/US\$ de 1,7794 em janeiro e terminou a R \$ / US\$ 1,6930 (BACEN, 2013). Esta apreciação do câmbio encarece o produto agrícola brasileiro no mercado internacional, tirando a competitividade do país e prejudicando a renda do produtor rural.

De acordo com Lazzarini e Nunes (1998), a perda da eficiência na comercialização do óleo bruto também é influenciada por outros fatores, como: política protecionista de países desenvolvidos, privilegiando a importação de matérias-primas vis-à-vis de produtos processados; ineficiência de muitas processadoras nacionais (capacidade ociosa, logística desfavorável etc.); e o alto custo de carregamento de estoques de soja no Brasil, em função das altas taxas de juros.

Os EUA evidenciam, a partir dos seus dados do IVCR, uma sensível elevação no nível de vantagens competitivas na comercialização deste produto. Os valores encontrados passaram de 1,30, em 1995, para 2,97, no ano de 2010. Por fim, a Argentina apresentou o maior crescimento no índice de vantagens comparativas, atingindo 111,59 , em 2010, ante 72,83, em 1995. Nesse sentido, a liberalização dos mercados e o crescimento da demanda internacional promoveram melhora na estrutura da indústria processadora da oleaginosa e, por conseguinte, na competitividade do país portenho em nível mundial.

\subsubsection{Soja MESMO TRITURADA}

O índice VCR da soja mesmo triturada apresenta valores crescentes tanto para o Brasil quanto para a Argentina, indicando as vantagens comparativas na comercialização desta commodity. Em 2010, o índice portenho chegou a 28,42 ante 17,83 , em 1995. No Brasil, o valor exportado para o ano de 2010 chegou a US\$ 11.042.995,56 mil, o que representa $1.333 \%$ frente à venda efetivada para 1995, cujo valor foi de US\$ 770.425,46 mil (UN COMTRADE, 2013). Desse modo, os resultados do IVCR para o Brasil alcançaram 11,25, na metade da década de 1990, e 21,35, em 2010. Segundo Waquil et al. (2004), a abertura comercial, a estabilização econômica e a utilização do aporte tecnológico incentivaram a ampliação da eficiência produtiva nos diversos segmentos da cadeia agroindustrial da soja e, mais especificamente, da soja mesmo triturada. Com isso, permitiu com que a 
Argentina e o Brasil elevassem a competitividade de suas exportações no comércio internacional.

Além disso, no caso do Brasil, é importante ressaltar também a intensificação da relação bilateral com a China, que, a partir de 2009 , consolidou-se como principal parceiro comercial conforme MAPA (2013). A China, desde sua acessão à OMC, em 2001, vem passando por um processo intenso de modernização de sua economia e de integração aos fluxos comerciais e de investimentos. No entanto, por se tratar de um país populoso e com poucas terras agricultáveis, o tema que mais preocupa o governo chinês é a segurança alimentar. $\mathrm{O}$ item soja mesmo triturada é um dos componentes mais importantes na alimentação chinesa e também empregado como ração para os animais. Sua importação é direcionada, principalmente, para a fabricação do óleo e do farelo (APEX, 2011).

Apesar de não ser autossuficiente na produção de alimentos, a China adota, de forma contraditória, práticas protecionistas na importação dos mesmos. A escalada tarifária é um dos métodos utilizados pelo país para desestimular a importação de produtos processados (OLIVEIRA; CARNEIRO, 2011). Uma maior incidência de tarifas de importação, por exemplo, para o óleo de soja, em vez do grão, acaba por induzir as importações do produto bruto, com baixo valor agregado. Dessa forma, o processamento do grão é feito em território chinês, gerando maiores renda e emprego (LOPES et al., 2013).

Os percentuais aplicados pelo governo chinês aos produtos brasileiros são: $3 \%$ para soja mesmo triturada; $5 \%$ para o farelo de soja; e $9 \%$ para óleo bruto ou fracionado. Além da estrutura tarifária complexa e restritiva, a China impõe também barreiras não tarifárias às importações, como: registro, documentação e procedimentos aduaneiros; inspeção aduaneira; restrições quantitativas (quotas); proibição de importação; monopólio importador - apenas as empresas estatais possuem direito a comercializar estes itens - e outras exigências internas (MDIC, 2013).

Já para os EUA, observou-se uma queda no IVCR, passando de 6,47, em 1995, para 5,68, em 2010. Isso significa que as exportações do país estadunidense foram relativamente menores do que as realizadas mundialmente.

\subsubsection{FARELO de SOJA}

Por último e ainda que os resultados alcançados tenham superado uma unidade e revelado as vantagens comparativas dos países na comercialização em nível internacional, o farelo da soja teve uma elevação mais expressiva para a Argentina, quando comparado ao Brasil e aos EUA. Como se trata de um produto homogêneo, ou seja, com pequenas possibilidades de diferenciação, a estratégia desses países líderes na produção e exportação está na redução de custos operacionais e de comercialização, objetivando, assim, o aumento da margem de lucro (BARBOSA; NOGUEIRA Jr, 2007). Supostamente essa estratégia, que é prática convencional por todo grande player, tem sido utilizada pela Argentina, que revelou uma elevação no IVCR, para o farelo da soja, de 42,24, em 1995, para 82,80, em 2010. No que tange ao IVCR brasileiro, observa-se uma redução bastante relevante, saindo do patamar de 37,25, em 1995, para 16,18 , em 2010. Essa queda também é explicada pelos mesmos motivos que foram citados para o óleo bruto da soja.

Já os EUA passaram de 1,46, em 1995, para 1,68, em 2010. De acordo com os resultados obtidos para os EUA, é possível sugerir que seu desempenho está diretamente ligado ao programa de subsídios do governo. A participação do Estado na economia agrícola e no comércio mundial contraria diretamente o objetivo do livre comércio que o próprio país impõe como regra geral. Contudo, enquanto o governo continuar subvencionando diretamente as exportações estadunidenses do grão da soja, é difícil exigir que outros países abandonem suas políticas protecionistas.

\section{CONSIDERAÇÕES FINAIS}

Este artigo analisou a competitividade das exportações do Brasil, da Argentina e dos EUA no que se refere ao complexo soja. Além disso, mensurou o grau de concentração dessas exportações, a partir da análise da participação dos seus três principais mercados consumidores, para cada produto proposto neste estudo.

Primeiramente, foram apresentadas as três principais medidas de competitividade desses países na produção e no comércio da soja: parcelas de mercado em valor, produção agrícola e produtividade. Os indicadores refletiram de forma significativa o aumento da capacidade dos países sul americanos. A Argentina, por exemplo, mais do que quadruplicou sua produção, alcançando, em 2010, uma participação de 19,88\% em nível mundial. Já o Brasil passou de 20,23\%, em 1995, para $25,95 \%$, em 2010. Por fim, os EUA, mesmo ampliando sua produção de grãos no período, apresentaram um recuo de 12,42 pontos percentuais no market share. 
Com relação à produtividade, verificou-se certa uniformidade uma vez que o Brasil, a Argentina e os EUA exibiram, para o ano de 2010, os seguintes valores, respectivamente: $2.947,2.905 \mathrm{e}$ 2.922. Todos os três possuem produtividade superior à média mundial para o mesmo ano, que foi de 2.583. Por fim, em relação ao comércio internacional, identificou-se o país estadunidense como o principal exportador, com uma participação de $47,69 \%$ para o último ano proposto para análise. O Brasil ocupou a segunda colocação, com $28,34 \%$, seguido da Argentina, com apenas 12,80\%.

O segundo objetivo deste estudo foi analisar os estudos empíricos que abordaram este tema. Foi possível observar que o Brasil vem investindo em novas tecnologias, elevando sua produtividade com o intuito de manter o bom desempenho no comércio internacional. Seu potencial competitivo aliado ao aumento da demanda de produtos do agronegócio faz o país desenvolver-se, mantendo assim, boas perspectivas de crescimento e liderança nos mercados onde atua.

Por fim, o objetivo principal do estudo foi analisar a competitividade das exportações da soja mesmo triturada, do farelo de soja, da farinha de soja e do óleo de soja bruto e fracionado do Brasil, da Argentina e dos EUA e identificar o grau de concentração dos principais mercados de exportação desses países para os anos de 1995 e de 2010. A partir da mensuração da $\mathrm{CR}_{3}$, foi possível observar que para a Argentina, apenas dois produtos dos cinco estudados tiveram aumento na concentração entre os três principais parceiros comerciais. O primeiro foi a soja mesmo triturada, que aumentou em 33 pontos percentuais, entre 1995 e 2010, seguido pelo óleo de soja bruto, com ampliação de 7,87 pontos percentuais, para o mesmo período analisado. Já com relação à queda na concentração nos principais destinos das exportações portenha, aponta-se o farelo de soja, com 16,57 pontos percentuais. O Brasil teve a desconcentração do óleo de soja fracionado como resultado mais expressivo uma vez que apresentou uma diminuição no patamar de 35,95 pontos percentuais, entre 1995 e 2010 . O oposto ocorreu com o óleo de soja bruto, com aumento de 4,74 pontos percentuais, e a soja mesmo triturada, que mostrou um aumento de 2,93 pontos percentuais, no período. Para os EUA, a soja mesmo triturada foi o produto com maior índice de concentração entre os dois anos propostos na pesquisa. Tal fato representou uma elevação de 27,54 pontos percentuais, seguido do óleo de soja mesmo fracionado, que apresentou um aumento no seu índice de
11,45 pontos percentuais a concentração dos três principais países.

Em relação à mensuração do IVCR, principal objetivo deste estudo, observou-se vantagens comparativas para todos os produtos/países, nos anos de 1995 e 2010. A exceção foi o produto farinha de soja para o Brasil e a Argentina, que apresentaram valores abaixo de uma unidade. Embora o agronegócio da soja na Argentina se mostre mais voltado à exportação de farelo e óleo (fracionado ou bruto) que do o Brasil e os EUA, os índices mensurados revelam que o país possui alta competitividade também na soja mesmo triturada, passando de 17,83, em 1995, para 28,42, em 2010.

Para o Brasil, verificou-se vantagem no IVCR para todos os demais produtos, sendo que a soja mesmo triturada apresentou maior vantagem comparativa em 2010, com índice de 21,35, em comparação ao valor de 11,55 , em 1995 . O oposto foi verificado para o óleo bruto e o farelo de soja. O primeiro apresentou uma redução de 36,50 para 11,38 enquanto que o segundo passou de 37,25 para 16,18 , para os dois períodos propostos para análise. Estas vantagens, segundo Waquil et al. (2004), advêm da abertura comercial, da estabilização econômica e da utilização do aporte tecnológico, que incentivaram de forma significativa a ampliação da eficiência produtiva. Além destes fatores, o menor custo da produção e, ainda, a possibilidade do aumento do cultivo via incorporação de novas áreas também corroboram para os valores encontrados no IVCR brasileiro.

É importante ressaltar que para ambos os países sul americanos, um aspecto que influenciou para análise dos índices de vantagem comparativa foi a estrutura tributária sobre as exportações da soja mesmo tritura e seus derivados. No caso do país portenho, a incidência mais elevada é direcionada para o grão, com $35 \%$, enquanto que o farelo, a farinha e o óleo bruto ou fracionado registram uma alíquota de $32 \%$ (BOLSA DE COMÉRCIO DE ROSÁRIO, 2013). Já o Brasil, preferiu desonerar as exportações do grão do ICMS. Assim, com o fim dessa tributação, aumentou a atratividade da oleaginosa no comércio internacional.

E importante ressaltar que as evidências empíricas apresentadas pelo Brasil têm suscitado que o país está experimentando uma reversão na sua pauta exportadora no sentido de uma tendência de reprimarização. Ou seja, haveria a tendência de retroceder a padrões anteriores, onde produtos de baixo valor agregado dominavam o comércio internacional. Há um debate sobre esse tema, pois, por um lado, não há problema em 
continuar exportando produtos nos quais o país possui vantagem comparativa, já que alguns países desenvolvidos cresceram baseados na exportação de produtos primários. No entanto, por outro lado, há o argumento de que países abundantes no setor primário tendem a crescer mais lentamente do que aqueles que produzem manufaturas mais intensivas em tecnologia e as exportam para o comércio internacional.

Por fim, observou-se para os EUA índices menores quando comparados aos do Brasil e da Argentina, porém verifica-se que o país permanece com a liderança tanto na produção dos cinco produtos analisados neste trabalho quanto nas exportações de apenas três deles, a saber: a farinha de soja, o óleo fracionado e a soja mesmo triturada (USDA, 2013). Os dois produtos que tiveram queda do IVCR foram o óleo fracionado e a soja mesmo triturada. O primeiro produto passou de 2,33 para 1,43 enquanto que o segundo alcançou 5,68 ante 6,47 entre os anos de 1995 e 2010. Os EUA, apesar de apresentar menores custos nos insumos e no transporte interno (BERTRAND et al., 2012), não conseguem, via resultados mensurados nesta pesquisa, ser competitivos com Brasil e Argentina, exceto na farinha de soja. Além disso, uma das razões para a discussão sobre o comércio desleal é o subsídio concedido por países desenvolvidos, como os EUA, que traria uma competitividade artificial.

Por fim, observa-se que a economia mundial da soja está cada vez mais competitiva em termos comerciais. Supõe-se que a oleaginosa permanecerá com a tendência de alta no que se refere ao consumo devido a dois principais motivos. $\mathrm{O}$ primeiro está no crescimento da renda mundial e, consequentemente, no consumo do grão e de seus derivados. Vale lembrar que a soja também é um insumo importante para a ração animal. $\mathrm{O}$ segundo fator, por sua vez, se refere à estabilidade econômica e política mundial bem como a abertura comercial de vários países membros da OMC.

Como sugestão para trabalhos futuros, propõe-se a realização de uma análise a partir da qual seja possível analisar a inserção do Paraguai e Uruguai no mercado da soja e derivados bem como suas participações no comércio internacional. Juntamente com o Brasil e Argentina (América do $\mathrm{Sul}$ ), ambos os países vem ocupando importantes posições entre os dez maiores produtores (USDA, 2013). Além do clima favorável e de políticas públicas voltadas para o setor agrícola, o baixo custo da terra permite aos agricultores da região atender ao aumento da demanda mundial.
Concluindo, o grande desafio que se tem para o mercado da soja e seus derivados está em promover o livre comércio e o desenvolvimento das nações como um todo. Assim, a eliminação de barreiras tarifárias e não tarifárias bem como outros mecanismos protecionistas possibilitam reforçar as vantagens comparativas dos países, aumentando assim as possibilidades de criação - ou o aumento - o comércio em nível em nível global.

\section{REFERÊNCIAS BIBLIOGRÁFICAS}

\author{
AGÊNCIA BRASILEIRA DE PROMOÇÃO DE \\ EXPORTAÇÕES E INVESTIMENTOS. APEX. \\ Disponível em: <http://www2.apexbrasil.com.br/>. \\ Acessado em: 14 ago. 2013.
}

AGRICULTURAL RESERCH SERVICE. ARS. Disponível em: $<$ http://www.ars.usda.gov>. Acessado em: 4 jun. 2013.

ALBUQUERQUE; N. Gustavo et al. O Impacto da Desoneração do ICMS nas Exportações sobre a Arrecadação no Ceará. In: ENCONTRO DA ASSOCIAÇÃO NACIONAL DE PÓS GRADUAÇÃO E PESQUISA EM ADMINISTRAÇÃO, XXXIV., Rio de Janeiro (RJ), 2010. Anais... ANPAD: Rio de Janeiro, 2010.

BALASSA, B. Trade Liberalization and "Revealed" Comparative Advantage. The Manchester School of Economic and Social Studies, v. 32, p. 99-123, 1965.

BANCO CENTRAL DO BRASIL. BACEN. Disponível em < http://www.bcb.gov.br> $>$. Acessado em: 04 jun. 2013.

BARBOSA, Z. Marisa; NOGUEIRA Jr., Sebastião. (As)simetrias entre as Agroindústrias da Soja no Brasil e na Argentina. Revista de Economia Agrícola, São Paulo, v. 54, n. 1, p. 87-107, 2007.

BATALHA, O. Márcio et al. (Orgs.). Agronegócio no Mercosul: Uma Agenda para o Desenvolvimento. São Paulo: Atlas, 2009.

BERTRAND, P. Jean et al. Fatores Determinantes da Competitividade da dos Principais Países Exportadores do Complexo Soja no Mercado Internacional. Organizações Rurais \& Agroindustriais, Lavras, vol. 14, n. 2, p. 227-242, 2012.

BOLSA DE COMÉRCIO DE ROSÁRIO. BCR. 
Disponível em: http://www.bcr.com.ar. Acessado em: 2 jun. 2013.

BRUM, A. L. A economia mundial da soja: impactos na cadeia produtiva da oleaginosa no Rio Grande do Sul 1970-2000. Ijuí: Ed. Unijuí, 2002.

CORONEL, Daniel A. et al. A competitividade da produção de soja no mato grosso do sul e na região de Ponta Porã: uma abordagem através das vantagens comparativas. In: CONGRESSO DA SOCIEDADE BRASILEIRA DE ECONOMIA, ADMINISTRAÇÃO E SOCIOLOGIA RURAL, XLV., Londrina (PR), 2007. Anais... Piracicaba: SOBER, 2007.

CORONEL, Daniel A. et al. Análise da Competitividade das Exportações do Complexo Soja Brasileiro de 1995 a 2006: Uma Abordagem de Market-Share. Revista de Economia Contemporânea, Rio de Janeiro (RJ), v. 13, p. 281-307, 2009.

CORONEL, Daniel A. et al. Vantagens comparativas reveladas e orientação regional das exportações do complexo soja brasileiro. In: CONGRESSO DA SOCIEDADE BRASILEIRA DE ECONOMIA, ADMINISTRAÇÃO E SOCIOLOGIA RURAL, XLVI., 2008., Rio Branco (AC). Anais... Piracicaba: SOBER, 2008.

CORONEL, Daniel. A.; DESSIMON. Vantagens Comparativas Reveladas e Orientação Regional da soja brasileira em relação à China. In: $\mathrm{CON}$ GRESSO DA SOCIEDADE BRASILEIRA DE ECONOMIA, ADMINISTRAÇÃO E SOCIOLOGIA RURAL, XLV., Londrina (PR), 2007. Anais... Piracicaba: SOBER, 2007.

DEBAR, Jean-Christophe. Les politiques de soutien à l'agriculture em Europe et aux États-Unis vues à travers lês chiffres. In: Europe/États-Unis: Regards croisés sur les politiques agricoles. Colloque de la Societé Française d'Economie Rurale, SFER, Paris (France), oct. 2002.

FARINA, Elizabeth. Competitividade do Sistema Agroindustrial da Soja. São Paulo, nov. 1993.

FERRAZ, J. C. et al. Made in Brazil: desafios competitivos para a indústria. Rio de Janeiro: Campus, 1997.

FIGUEIREDO, A. M.; SANTOS, M. L. Evolução das Vantagens Comparativas do Brasil no Comércio
Mundial da Soja. Revista de Política Agrícola, Brasília, n. 5, p. 9-16, 2005.

FOOD AND AGRICULTURE ORGANIZATION OF THE UNITED NATIONS. FAOSTAT. Disponível em: <http://faostat.fao.org $>$. Acessado em: 10 abr. 2013.

GIORDANO, S.R. Competitividade Regional e Globalização. Tese de Doutorado. Faculdade de Filosofia, Letras e Ciências Humanas da Universidade de São Paulo, 1999.

HAGUENAUER, L. Competitividade: Conceitos e Medidas. Uma Resenha da Bibliografia Recente com ênfase no Caso Brasileiro. Rio de Janeiro: IEI / UFRJ, 1989. Texto para discussão n. 211.

ILHA, Adayr da Silva; SOUZA, Maurício Jorge Pinto de. Índices de vantagem comparativas reveladas e orientação regional para alguns produtos do agronegócio brasileiro no período de 1992 a 2002. In XLIII CONGRESSO BRASILEIRO DE ECONOMIA E SOCIOLOGIA RURAL, XLIII., 2005., Ribeirão Preto. Anais... Piracicaba: SOBER, 2005.

$\mathrm{KOCH}, \mathrm{J}$. V. Industrial Organization and Prices. 2 ed., New Jersey: Englewood Cliffs, 1980. 504p.

KUPFER, D. Padrões de Concorrência e Competitividade. Rio de Janeiro: IEI / UFRJ, 1993. Texto para discussão ${ }^{\circ} 265$.

LAZZARINI, S. G.; NUNES, R. Competitividade do sistema agroindustrial da soja. Brasília: IPEA, 1998.

LOPES, M. Mygre et al. Análise da Competitividade das Exportações Agrícolas Brasileiras para a China: Uma análise do Complexo Soja e Fumo. Revista Uniabeu, Rio de Janeiro, v.6, n. 13, p. 189-208, 2013.

MARTIN, S. Industrial Economics - Economic Analysis and Public Policy. 2nd ed. New Jersey: Prentice Hall, 1993.

MASSUQUETTI, Angélica et al. As relações comerciais agrícolas entre MERCOSUL e UE no período 2000-2010. In: CONGRESSO DA SOCIEDADE BRASILEIRO DE ECONOMIA, ADMINISTRAÇÃO E SOCIOLOGIA RURAL, 50., 2012. Vitória (ES). Anais... Piracicaba (SP): SOBER, 2012. 
MINISTÉRIO DA AGRICULTURA, DA PECUÁRIA E DO ABASTECIMENTO. MAPA. Disponível em: < http://www.agricultura.gov.br/>. Acessado em: 10 ago. 2013.

MINISTERIO DE AGRICULTURA, GANADERÍA y PESCA. MAGYP. Disponível em: $<\underline{\text { http:// }}$ www.minagri.gob.ar>. Acessado em: 10 maio 2013.

MINISTÉRIO DO DESENVOLIMENTO INDÚSTRIA E COMERCIO EXTERIOR. MIDIC. Secretária de Comércio Exterior (SECEX). Disponível em: < http://www.desenvolvimento.gov.br $>$. Acesso em: 22 fev. 2013.

MORO, Sueli; LEMOS, Mauro Borges. Competitividade Internacional das Exportações Estaduais e Brasileiras de Produtos do Complexo Soja. In: CONGRESSO BRASILEIRO DA SOCIEDADE BRASILEIRO DE ECONOMIA E SOCIOLOGIA RURAL, XXXVII., 1999, Foz do Iguaçu. Anais... Piracicaba: SOBER, 1999.

OLIVEIRA, I. T; CARNEIRO, F. L. BRICS: perfis tarifários em análise. Boletim de Economia e Política Internacional, Brasília, n. 6, p.7-18, abr./jun. 2011.

OXFORD COMMITTEE FOR FAMINE RELIEF. OXFAM. 2011. Disponível em: <http://www.oxfam. org>. Acessado em: 20 mar. 2013.

REIS, Magnus dos; AZEVEDO, Z. F. André. O impacto da criação do Mercosul no fluxo de comércio bilateral: uma abordagem com o modelo gravitacional. In: ENCONTRO NACIONAL DE ECONOMIA, XXXVI., 2008., Salvador. Anais... Niterói (RJ): ANPEC, 2008.

RUDELL; D. A., PRIEB, R. P. As Exportações Brasileiras da Soja em Grão Para a China no Período de 1995 a 2005. In: CONGRESSO DA SOCIEDADE BRASILEIRA DE ECONOMIA, ADMINISTRAÇÃO E SOCIOLOGIA RURAL, XLVI., 2008., Rio Branco (AC). Anais... Piracicaba: SOBER, 2008.

SCHUMPETER, J. Capitalismo, socialismo e democracia. São Paulo. Zahar, 1994.

SECRETARÍA DE AGRICULTURA, GANADERÍA, PESCA y ALIMENTOS. SAGPyA. Disponível em: <http://www.minagri.gob.ar $>$. Acessado em: 12 maio 2013.
SENNA, Ana Júlia Teixeira; MELLO, Eulalie de Souza. Análise do Comportamento dos preços dos produtos do complexo soja. In: CONGRESSO DA SOCIEDADE BRASILEIRA DE ECONOMIA, ADMINISTRAÇÃO E SOCIOLOGIA RURAL, XLVI., 2008., Rio Branco (AC). Anais... Piracicaba: SOBER, 2008.

SILVA, A. Fernanda et al. Padrão da inserção brasileira no mercado internacional de grãos. Estudos do Cepe, Santa Cruz do Sul, n.31 p.73-96, 2010.

SILVA, C. A. B.; BATALHA, M. O. Competitividade em sistemas agroindustriais: metodologia e estudo de caso. In: WORKSHOP BRASILEIRO DE GESTÃO DE SISTEMAS ALIMENTARES, 2., 1999, Ribeirão Preto. Anais... Ribeirão Preto: PENSA/FEA/USP, 1999.

UNITED COMMODITY TRADE STATISTICS. UN CONTRADE. Disponível em: $<\underline{\mathrm{http}} / / /$ comtrade.un.org/>. Acessado em: 31 maio 2013.

UNITED NATIONS CONFERENCE ON TRADE AND DEVELOPMENT. UNCTAD. Disponível em: $<$ http://unctad.org/en/Pages/Home.aspx $>$ Acessado em: 12 mar. 2012.

UNITED STATES DEPARTMENT OF AGRICULTURE. USDA. Disponível em: <http://www.usda. gov/wps/portal/usda/usdahome>. Acessado em: 20 jan. 2013.

VALARINI, Juliana P.; KUWAHARA, Mônica Y. O Mercado da Soja: Evolução da Commodity Frente aos Mercados Internacional e Doméstico. Revista da Graduação em Administração, Ciências Contábeis e Ciências Econômicas, São Paulo, vol. 4, n. 6, jan.-jun., 2007.

VICENTE, José R. Competitividade do Agronegócio Brasileiro, 1997-2003. Revista de Economia Agrícola, São Paulo (SP), v. 52, n. 1, p. 5-19, 2005.

WAQUIL, P. D. et al. Vantagens comparativas reveladas e orientação regional das exportações agrícolas brasileiras para a União Europeia. Revista de Economia e Agronegócio, Viçosa, MG, v. 2, n. 2, p. 137-160, 2004 